2020, Volume 10, International Conference Globalization, Innovation and Development. Trends and Prospects (G.I.D.T.P.), pages: 86-94 | https://doi.org/10.18662/lumproc/gidtp2018/11

\section{Promoting Valahia University of Targoviste Among High-school Pupils and Students}

\section{Maria Cristina STEFAN ${ }^{1}$,} Violeta Andreea

ANDREIANA ${ }^{2}$, Dorin IANCU $*^{3}$

${ }^{1}$ Valahia University of Targoviste, Romania, e-mail:

crys07stefan@yahoo.com

2 Valahia University of Targoviste, Romania, e-mail:

andreea.vivi@yahoo.com

${ }^{3}$ Valahia University of Targoviste, Romania, e-mail: dorin iancu04@yahoo.com Corresponding author
Abstract: In the context of a fierce competition between Romanian universities, due to the fact that many of high school students were unable to pass the baccalaureate exam, their lack of interest in continuing to study and the choice of students to migrate abroad, VUT tries to cope with the challenges and be one of the most famous universities in the South Muntenia Region. The first part of the lecture is represented by an analysis, based on the data from the internet, on sites like uefiscdi, capital, mediafax, valahia etc., the analysis is about following promoting strategies used in the prestigious international universities and identifying the local methods adopted by the universities from Romania. In the second part, two surveys were conducted to give the university "some useful tips" about how to attract students and master students in a great academic environment. The first survey was conducted among the students of the best five high schools in Târgovişte and we found out their requirements in the university choices they will choose, fundamental aspects in the preparation of a VUT student promotion plan. The second survey aimed to understand the reasons of why the students do not want to continue mater studies at VUT. The results were necessary for preparing a set of promoting actions of the VUT among students.

Keywords: university; students; promoting.

How to cite: Stefan, M.C., Andreiana, V.A., \& Iancu, D. (2020). Promoting Valahia University of Targoviste Among High-school Pupils and Students. In I. Panagoreț \& G. Gorghiu (vol. ed.), Lumen Proceedings: Vol. 10. International Conference Globalization, Innovation and Development. Trends and Prospects (G.I.D.T.P.) (pp. 86-94). Iasi, Romania: LUMEN Publishing House.

https://doi.org/10.18662/lumproc/gidtp2018/11 


\section{Introduction}

The problems, faced by the higher education system, are related to the decrease of the state budget financing, the decrease of the number of students, the lack of motivation of the teachers and the students, the instability of the business environment and the impossibility of dealing with a highly competitive environment are in difficulty higher education units in terms of the ability to meet the promotion costs in order to attract students [3]. In this regard, in the present paper, we proposed several directions of action which we consider less costly.

\section{Problem Statement}

For countries such as China, Portugal, Turkey, Austria, the Ministry of Education is responsible for coordinating and executing the promotion of the higher education institutions. The Ministry separately allocates a budget for promotional actions, which includes both national promotion and promotion at international level [2]. The Ministry's actions include all forms of promotion, including participation in educational fairs, conferences, and action plans [5]. Other activities of the Department of Promotion within the Ministry of Education include: collecting data from the higher education institutions of that state, as well as collecting and selecting information from the Twitter and Facebook social media. However, Romania faces the lack of an association / agencies to address the issues of promoting higher education, curricula, student recruitment, mobility, etc. [1].

We believe that a successful plan could be developed in partnership with the Ministry of Education and higher education institutions. In this sense, we shall analyse the current situation of promoting universities in Romania, especially Valahia University in Targoviste and we shall formulate some possible solutions for effective promotion.

\section{Research Questions/Aims of the research}

Two surveys were conducted among the students from the most popular high schools in Targoviste and among the students of UVT.

The objectives of the first survey were: the degree of knowledge of UVT offers; the reasons for which pupils from Targoviste choose other universities; pupils' recommendations for UVT. 
For the students' survey, the objectives pursued: the reasons why UVT students choose to study Master Programmes in other faculties; student satisfaction with the teacher training and the courtesy of secretaries; the degree of knowledge of the UVT offer.

\section{Research Methods}

Two surveys were conducted among the students in the most popular high schools in Târgovişte, where we chose 50 students to find out what their reasons are when they choose to continue their studies at a university. These high schools include: Ienăchiță Văcărescu National College, Constantin Carabella National College, Ion Ghica Economic College, Petru Cercel Theoretical High School and Mircea Voievod High School. 10 pupils, from the 12th grade, were elected, from each high school. detail."

The central hypothesis "Pupils do not know the UVT"s offer in

The survey unit is represented by 12th grade students in high schools with good results at the baccalaureate exam. The sampling method was simple, random sampling. The type of investigation was face-to-face, based on the questionnaire. The period for collecting the information was 13.02.2017 - 24.03.2017. The information has been processed using the EXCEL program.

For the second survey, we randomly chose 50 students from UVT to find out their reasons when choosing to continue their studies at a university, the students who answered the questionnaire belong to the Faculty of Economics, Faculty of Law and Administrative Sciences, Faculty of Political Sciences, Letters and Communication, Faculty of Environmental Engineering and Food Science and Faculty of Materials Engineering and Mechanics. Of each faculty were elected 10 students from the study years II and III.

The central hypothesis "Most students do not want to continue with the master studies."

The sample unit is represented by the students of the study years II and III of the UVT. The sampling method was simple, random sampling. The type of investigation was face-to-face, based on the questionnaire. The collection period was 27.03.2017 - 05.05.2017. The information has been processed using the EXCEL program. 


\section{Findings}

\subsection{The students' wishes in choosing the university centre}

In order to extract pertinent, correct and helpful information in the proposed analysis, we considered it appropriate to formulate hypotheses, which can be verified by correlating some of the questions of the first questionnaire addressed to the students of the mentioned high schools. These are:

- Top high school students: Ienăchiță Văcărescu National College and Constantin Carabella National College do not have UVT as their first option;

We find that $40 \%$ of the respondents opt for continuation of UVT faculties and 60\% want to leave Targoviste: $20 \%$ at Bucharest University, $14 \%$ at ASE and Police Academy and 12\% at University of Medicine and Pharmacy. Figure 1 graphically represents pupils' options for universities.

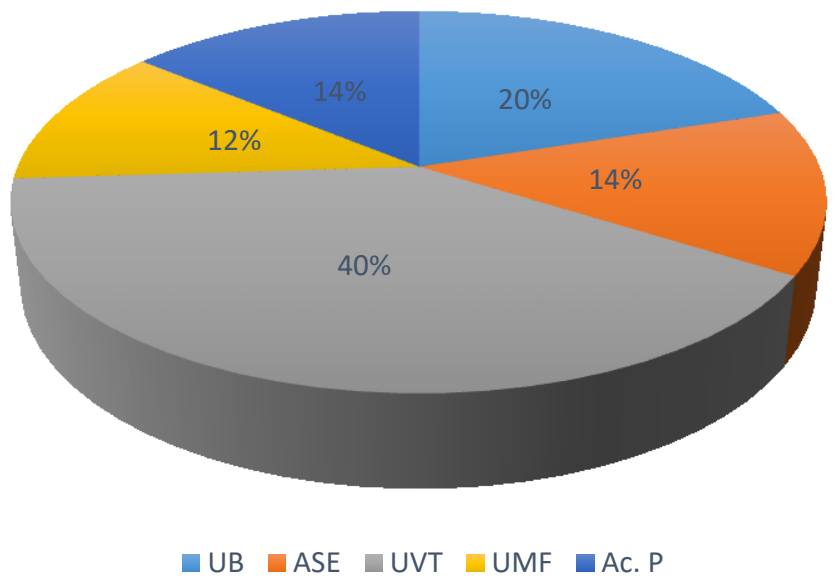

Figure 1. Pupils options for universities

- Students are dissatisfied with the possibility of a decent living in Târgovişte choose universities from other cities.

We understand that the lack of economic stability on the jobs market in Targoviste, well-paid jobs, investors, the ability to train and maintain a family are factors that push high school graduates to cities where all these are possible [4]. 
- The lack of UVT promotion leads to graduate pupils leaving in university centres in other cities.

$44 \%$ of the respondents recommended UVT to promote itself, because pupils in Targoviste do not know it very well. Those who have recommended this point go to universities outside Targoviste. Unfortunately, the lack of money funds prevents UVT from being promoted intensively through all channels and at regional and national level. However, we believe that through partnerships with school inspectorates, economic agents, and school principals it is possible to promote the university with little money.

- Pupils do not know the UVT offer in detail.

$50 \%$ of the respondents said that the UVT offer is partly known, only $24 \%$ know it and $26 \%$ do not know it at all. These results confirm suspicions such as "high school graduates do not study in a great number at UVT because their offer is not known". So, promotion is the only way to attract students to the UVT, because there are: the material base, the welltrained teachers, the costs are lower compared to other university centres...

- UVT Campus is an essential factor in choosing to continue studying at UVT.

$40 \%$ of the respondents believe that the main reason they would study in Târgovişte would be the university campus (Table 1).

Table 1. Students' wishes for UVT's choice

\begin{tabular}{lllllll}
\hline Reason & UB & ASE & UVT & UMF & Ac.P & TOTAL \\
Campus & 3 & 1 & 9 & 4 & 3 & 20 \\
Hostels & 3 & 1 & 1 & 1 & 1 & 7 \\
Teacher training & - & 2 & 5 & 1 & 1 & 9 \\
Proximity & 4 & 5 & 3 & - & 2 & 14 \\
TOTAL & 10 & 9 & 18 & 6 & 7 & 50
\end{tabular}

$36 \%$ of respondents say that they will continue their studies at UVT, and $50 \%$ of them say they are attracted by the new UVT campus, $28 \%$ would remain in Targoviste for the outstanding teacher training, 17\% chose the proximity to their house and $1 \%$ believes that the place in student hostels is the reason for choosing UVT. 


\subsection{Students Reasons for Continuing / Non-Continuing their Studies at $\boldsymbol{U V T}$}

In order to achieve the objectives, set out in the second survey, we have put forward some assumptions, which can be verified by correlating some of the questions of the second questionnaire addressed to the students. These are:

- Students who claim that the tuition fee is high do not want or are undecided in continuing their master studies.

Table 2. Continuation / non-continuation of master studies according to the perception of the tuition fee

\begin{tabular}{lllll}
\hline Tuition fee & Yes & No & Maybe & TOTAL \\
Law & 6 & 4 & 3 & 13 \\
Nor, nor & 9 & 12 & 5 & 26 \\
High & 4 & 3 & 4 & 11 \\
TOTAL & 19 & 19 & 12 & 50
\end{tabular}

Only $22 \%$ of the interviewed students responded that the tuition fee is high compared to the fees of other universities (Table 2). Of the total respondents who stated that the tuition fee is high, $63 \%$ are undecided or do not want categorically to pursue master courses.

- UVT support in finding a job for the student is essential for continuing his studies.

Of the total of interviewees, $38 \%$ do not want to continue their master studies, so they did not answer this question. Out of the 31 students, $58 \%$ believe that UVT should help them / recommend them in finding a job, and half of them should study in UVT.

Târgovişte.

- Well-paid job is the main reason why students leave

Table 3. Reasons for choosing other faculties for master studies

\begin{tabular}{lll}
\hline Reason & Other faculty & Percentage \\
Exigent teachers & 3 & 19 \\
No desired specialization & 6 & 38 \\
I want to leave Târgovişte to find a & 7 & 43 \\
well-paid job & & \\
TOTAL & 16 & 100
\end{tabular}


The main reason why students leave Targoviste and go to a College/Faculty in another city is finding a well-paid job (43\% chose this answer).

$38 \%$ claim that the specialization they want to study is not in the UVT offer. Among their recommendations we mention: medicine, psychology, pharmacy, viral marketing.

- Students who are happy with the teacher training want to study the masters at UVT.

Table 4. The satisfaction degree of the students towards the teaching staff of UVT

\begin{tabular}{cccccc}
\hline Students wishing to study at UVT & 5 & 4 & 3 & 2 & 1 \\
& 4 & 10 & 1 & - & - \\
$\mathrm{S}=(4 * 5)+(10 * 4)+(1 * 3) / 15=4,2$ & & & & &
\end{tabular}

As mentioned above, $30 \%$ of respondents said they would continue their master studies within the UVT (Table 4). Teachers' grades reflect a score of 4.2 which shows students' degree of satisfaction with teacher training. So, this is not a reason for student orientation to other university centres.

- Students who claim that UVT is not being promoted consider the offer to be restricted.

Of the total of 50 students participating in the survey, $56 \%$ consider the UVT offer to be restricted, $24 \%$ think it is diversified and $20 \%$ have diversification recommendations (mentioned in the previous hypothesis).

It can be seen from Table 13 that among those who believe that UVT is not being promoted enough, 93\% say that UVT offer is restricted. This is possible because they did not want to look for information by themselves, and UVT did not make efforts to inform future students and master students.

\section{Discussions}

We recommend offline and online promotion of the UVT educational offer to inform students about the UVT offer. Their details are presented below.

OFFLINE PROMOTION: advertising at local TV stations; advertising on Kiss FM TV channel; Ao posters in high schools; inviting the $\mathrm{X}, \mathrm{XI}$ and XII class students to visit the campus; organizing competitions within the UVT with student participation; organizing student graduation celebrations at UVT amphitheatres, roundtables for teachers, school 
headmasters and business representatives, employer-supported seminars for pupils and students; involvement of the City Hall and the County Council in attracting business partnerships and initiating collaborations; involvement of students in organizing the Ball of Freshmen at high schools.

ONLINE PROMOTION: creating Facebook, Twitter, Instagram; improving university and faculty sites, intense online activity, creating groups between students and students; e-mail marketing: informing students and inviting them by e-mail to participate in the competitions organized within the UVT; informing students about the benefits obtained by graduating from masters and doctoral studies in UVT.

And, in this case, the survey of students helped us identify their needs, dissatisfactions about the current situation in order to improve the offer and reach the potential master students.

The objectives are: promotion among students; diversification of the offer; making Targoviste a town where young people want to live; attracting students for Master and $\mathrm{PhD}$ studies.

In this regard, we recommend several possible directions of action for UVT, with the involvement of several actors to achieve these objectives. These would be: informing the final year students about the UVT offer; informing master students about existing doctoral areas; organizing seminars with students; expanding partnership with Targoviste City Hall; organizing competitions, scientific communications sessions and Olympiads; organizing student thematic sessions; involving students in volunteer actions; organizing special days with the theme: "let's go to the faculty by bike" or "who did you help today?"; student involvement in creating the advertisements for promotion; involvement of students in the Valahia Students Magazine; introducing new license specializations required by the labour market; the operation of a student canteen and a café.

\section{Conclusions}

Broadly speaking, the UVT offer is known by UVT students and masters, but getting closer to and empathizing with the student can be an advantage of the UVT for them to continue their studies and stay in Târgovişte.

All the goals were met, and the assumptions were verified. We consider the information obtained both for the management of Valahia University in Targoviste and for all the Romanian University centres. 


\section{References}

[1] Florea NV. Using branding to attract, recruit, and retain talented staff. Management \& Marketing Journal. 2011; 9(2): 283-297.

[2] Iancu D. Globalization of Competition. Valahian Journal of Economic Studies. Targoviste. 2014; 5(2): 51-54.

[3] Henard F, Diamond L, Roseveare D. Approaches to Internationalisation and Their Implications for Strategic Management and Institutional Practice. A Guide for Higher Education Institutions; 2012. Available from: https://www.oecd.org/education/imhe/Approaches $\% 20$ to $\% 20$ internationalisa tion $\% 20-\% 20$ final $\% 20-\% 20$ web.pdf [Accessed 2nd February 2015].

[4] Gheorghița E. Concurența din universitățile din București: care sunt facultățile cu cel mai mare număr de înscrieri; 2011. Available from:

https://www.mediafax.ro/social/concurenta-din-universitatile-din-bucuresticare-sunt-facultatile-cu-cel-mai-mare-numar-de-inscrieri-8504838 [Accessed 2nd February 2015].

[5] Economu V. Admitere facultate 2014. Universităţile din România în care se înregistrează cea mai mare concurență; 2014. Available from: http://www.mondonews.ro/admitere-facultate-2014-universitatile-dinromania-in-care-se-inregistreaza-cea-mai-mare-concurenta/ [Accessed 2nd February 2015]. 